\title{
Diurnal dynamics of the microbial loop in peatlands: structure, function and relationship to environmental parameters
}

\author{
Tomasz Mieczan • Monika Tarkowska-Kukuryk
}

Received: 14 November 2012/Revised: 23 May 2013/Accepted: 1 June 2013/Published online: 19 June 2013

(C) The Author(s) 2013. This article is published with open access at Springerlink.com

\begin{abstract}
The interactions between bacteria and heterotrophic protists are essential for the ecosystem ecology of peatlands. We tested the hypothesis that fertility of a habitat may significantly influence the diurnal dynamics of the abundance of individual components of the microbial loop, as well as the number and intensity of correlations between bacteria and heterotrophic protists. Samples were taken in raised and carbonate peat bogs in three seasons, four times a day: at dawn, at noon, at dusk and at night. The results indicate that microbial community responses to physical and chemical parameters are complex but dependent on peatlands' type and variable among microbes. Concentrations of nutrients may significantly influence the diurnal dynamics of the microbial communities. The most significant correlations occurred in the afternoon. At that time, the number and biomass of metabolically active bacteria correlated to the highest degree with concentrations of dissolved organic carbon, while in the evening, a clearly positive correlation between the abundance of bacteria and protists was observed. In a carbonate fen, the correlations were significantly weaker. Such knowledge will provide a more comprehensive understanding of the implication of chemical
\end{abstract}

Handling editor: Stefano Amalfitano

T. Mieczan $(\bowtie) \cdot$ M. Tarkowska-Kukuryk Department of Hydrobiology, University of Life Sciences, Dobrzańskiego 37, 20-262 Lublin, Poland

e-mail: tomasz.mieczan@up.lublin.pl disturbance on microbial functions in relation with nutrient and carbon dynamics.

Keywords Peatlands - Microbial loop - Bacteria . Flagellates $\cdot$ Testate amoebae $\cdot$ Ciliates

\section{Introduction}

Bacteria and heterotrophic protists constitute the 'microbial loop', which is a distinct and important element of the trophic food web in aquatic ecosystems (Azam et al., 1983). The microbial loop is a model of the pathway of carbon flow and nutrient cycling through microbial components of aquatic communities. In addition to bacterial uptake of nonliving organic matter, many direct links exist among algae, bacteria and other heterotrophic microbes. By these numerous pathways, fixed organic carbon can be recovered, often into larger sized microorganisms that may be more available for consumption by larger organisms (Azam et al., 1983). Thus, the controlling factors in microbial loop components and the relationships between bacteria and heterotrophic protists are important for understanding the functioning of the peatlands ecosystem. Bacteria are capable of rapid changes, probably faster than other organisms, regarding their growth, biomass production, etc. In addition, factors controlling the seasonal and daily dynamics of the microbial loop may be fundamentally different. Seasonal changes in microbial activity would be 
expected to be strongly affected by physical and chemical parameters, most notably by temperature (Chróst et al., 2009). Short-term changes, by contrast, may be dependent on biological features of the community (Macek et al., 2001; Mieczan, 2010). Studies on seasonal and daily relations among microbial loop components suggested that dial correlations are stronger, especially in eutrophic lakes. In the dial cycle, all components of the microbial loop are most strongly correlated with DOC concentrations (Kalinowska, 2004). Any information on the relations between microbial loop components (bacteria and protists) in microhabitats of peatland ecosystems is particularly scarce (Gilbert et al., 1998a, b; Mitchell et al., 2003; Mieczan, 2007). Among unicellular organisms, testate amoebae are the most common ones in peatlands. Due to the clear predominance of testate amoebae in peatland ecosystems, they are recognised as fulfilling the main function in matter and energy flow (Mitchell et al., 2000, 2003; Nguyen-Viet et al., 2007). Those microorganisms are significant consumers of bacteria, flagellates and algae, and participate in mineralisation of organic matter and circulation of biogenic compounds (Gilbert et al., 1998a, b; Wilkinson \& Mitchell, 2010; Mieczan et al., 2012). According to Gilbert et al. (1998a), the size of heterotrophic protists determines their position in the food web in peatlands. Literature, however, includes hardly any papers on trophic relations in such ecosystems. Gilbert et al. (1998a, b) suggest that testate amoebae may be of high significance in controlling the number of bacteria in the environment of Sphagnum mosses on ombrotrophic peatlands. Such relations on other types of peatlands have not been studied so far. Until recently, only a few studies discussed the ecology of testate amoebae in fens (Payne \& Mitchell, 2007; Jassey et al., 2010; Lamentowicz et al., 2010; Payne, 2011). The fact that peatland ecosystems are distinguished by a low concentration of nutrients and the highest concentrations of organic matter indicates the key role of the microbial loop in their functioning. Hence, further studies are necessary to determine trophic relations between individual components of the microbial loop in various types of peatlands, including carbonate-rich fens which are particularly valuable and rarely occur in other parts of Europe. The lack of sufficient information in the available literature provided us with the inspiration to initiate studies on that specific group of organisms in peatlands. A thorough insight into not only the seasonal but also diurnal dynamics of the abundance and biomass of those microorganisms will be particularly important for a better understanding of matter and energy circulation in the ecosystem (microbial loop), as well as for recognising mutual species-environment relations. The primary objective of this study was, therefore, to determine the diurnal dynamics of individual components of the microbial loop in various types of peatlands. Studies were carried out in order to verify the hypothesis that fertility of a habitat may significantly influence the diurnal dynamics of the abundance of individual components of the microbial loop, as well as the number and intensity of correlations among bacteria, flagellates, testate amoebae and ciliates.

The objectives of this study were to assess (1) the diurnal dynamics of the microbial communities (heterotrophic bacteria, flagellates, testate amoebae and ciliates), (2) the relationships among the microbial loop components and (3) the effects of physical and chemical factors on the microbial community structure in different type of peatlands.

\section{Materials and methods}

Study site

The study area comprised two peatlands: raised bog Durne Bagno and rich carbonate fen Bagno Bubnów (Poleski National Park, eastern Poland, $51^{\circ} \mathrm{N}, 23^{\circ} \mathrm{E}$ ). The peatlands selected for this study represent various trophy and vegetation types. In raised bog, the vegetation is dominated by Eriophorum vaginatum (L.), Carex acutiformis Ehrhart., Carex gracilis Curt., Sphagnum angustifolium (C.C.O. Jensen ex Russow), Sphagnum cuspidatum Ehrh. ex Hoffm. and Sphagnum magellanicum Bird. The carbonate fen is colonised by Phragmites australis (Car.), Carex acutiformis Ehrhart., Calliergonella cuspidata (Hedw.) and Utricularia sp. (Table 1).

Abiotic variables

In each plot, temperature, conductivity, $\mathrm{pH}$, dissolved oxygen (DO), chlorophyll $a, \mathrm{P}_{\text {tot }}, \mathrm{N}_{\text {tot }}$, dissolved organic carbon (DOC) and total organic carbon (TOC) were measured. Physical and chemical analyses were 
Table 1 Physical and chemical characteristics of water in investigated peatlands (average values for period April-November $2009 \pm$ standard deviation)

\begin{tabular}{|c|c|c|c|c|c|c|c|c|c|}
\hline Microhabitat & $\begin{array}{l}\text { WTD } \\
(\mathrm{cm})\end{array}$ & $\mathrm{pH}$ & $\begin{array}{l}\text { DO } \\
\left(\mathrm{mg} \mathrm{l}^{-1}\right)\end{array}$ & $\begin{array}{l}\text { Chlorophyll } \\
a\left(\mu \mathrm{g}^{-1}\right)\end{array}$ & $\begin{array}{l}\text { Conduct } \\
\left(\mu \mathrm{S} \mathrm{cm}^{-1}\right)\end{array}$ & $\mathrm{N}_{\text {tot }}\left(\mathrm{mg} \mathrm{l}^{-1}\right)$ & $\mathrm{P}_{\text {tot }}\left(\mathrm{mg} \mathrm{l}^{-1}\right)$ & $\begin{array}{l}\text { DOC } \\
\left(\mathrm{mg} \mathrm{l}^{-1}\right)\end{array}$ & $\begin{array}{l}\text { TOC } \\
\left(\mathrm{mg} \mathrm{l}^{-1}\right)\end{array}$ \\
\hline \multicolumn{10}{|l|}{ Raised bog } \\
\hline SA & $17 \pm 5$ & $3.3 \pm 1$ & $8.3 \pm 3.3$ & $98 \pm 63$ & $29 \pm 6.4$ & $1.121 \pm 0.02$ & $0.222 \pm 0.11$ & $18 \pm 4$ & $54 \pm 11$ \\
\hline $\mathrm{SC}$ & $15 \pm 7$ & $3.1 \pm 1$ & $10.1 \pm 3.1$ & $94 \pm 9.3$ & $27 \pm 8.2$ & $1.13 \pm 0.23$ & $0.239 \pm 0.11$ & $21 \pm 3$ & $56 \pm 8$ \\
\hline \multicolumn{10}{|l|}{ Carbonate fen } \\
\hline PH & $49 \pm 3$ & $7.9 \pm 1$ & $8.3 \pm 2.1$ & $140 \pm 7$ & $321 \pm 17$ & $2.111 \pm 0.78$ & $0.311 \pm 0.12$ & $8 \pm 2$ & $15 \pm 2$ \\
\hline $\mathrm{CR}$ & $41 \pm 3$ & $8.2 \pm 1$ & $8.5 \pm 2.3$ & $112 \pm 9$ & $311 \pm 23$ & $2.112 \pm 0.98$ & $0.290 \pm 0.16$ & $9 \pm 3$ & $14 \pm 4$ \\
\hline UT & $20 \pm 5$ & $7.2 \pm 1$ & $6.9 \pm 1.8$ & $164 \pm 11$ & $421 \pm 25$ & $1.563 \pm 0.96$ & $0.368 \pm 0.18$ & $11 \pm 2$ & $23 \pm 4$ \\
\hline CA & $22 \pm 6$ & $7.1 \pm 1.5$ & $6.7 \pm 1.8$ & $102 \pm 8$ & $399 \pm 31$ & $1.468 \pm 0.48$ & $0.378 \pm 0.13$ & $12 \pm 4$ & $21 \pm 6$ \\
\hline
\end{tabular}

SA Sphagnum angustifolium, SC Sphagnum cuspidatum, PH Phragmites australis, CR Carex acutiformis, UT Utricularia sp., CA Calliergonella cuspidate, WTD water table depth

performed according to standard methods for hydrochemical analyses (Golterman, 1969). Temperature, conductivity, $\mathrm{pH}, \mathrm{DO}$ were assessed at the sites with a multiparametric probe (Hanna Instruments), TOC was analysed by multiparametric UV analyzer (Secomam, France), $\mathrm{P}_{\text {tot }}$ by the colorimetric method and $\mathrm{N}_{\text {tot }}$ by Kjeldah's method. Water samples for chlorophyll $a$ and DOC analyses were taken four times a day: at dawn (4 a.m.), at noon (12 a.m.), at dusk (7-8 p.m.) and at night (12 p.m.). Chlorophyll $a$ was determined spectrophotometrically after extraction with ethanol. DOC analysis was performed using a wet potassium persulfate digestion with O/I Corporation Model 700 TOC analyzer.

\section{Microbial communities}

Fieldwork was done on a monthly basis from April to November 2009. Round-the clock studies on the abundance of individual components of the microbial loop were carried out once in spring (April), summer (July) and autumn (November). In order to determine changes in the number of microorganisms, during each of the season, samples were taken four times a day: at dawn (4 a.m.), at noon (12 a.m.), at dusk (7-8 p.m.) and at night (12 p.m.). The microsites consist of the patches $\left(2-4 \mathrm{~m}^{2}\right)$ of different peat mosses and belts of vascular plants. The distance between the patches was of ca. $15 \mathrm{~m}$. Three samples were taken at each time from each of the sites. The total dataset consists of 168 samples. During each sampling occasion, three samples were collected from each microhabitat. In raised bog, microbial communities were sampled in hollows, between Sphagnum angustifolium and Sphagnum cuspidatum (total of 72 samples). In the carbonate fen, microbial communities were collected in belts of Phragmites australis, Carex acutiformis Ehrhart., Utricularia sp. and Calliergonella cuspidata (96 samples in total). At each type of microhabitat water was sampled using a plexiglass corer (length $1.0 \mathrm{~m}$, $\varnothing 50 \mathrm{~mm}$ ). The plexiglass corer was closed at each end with a cork and then water samples were collected using a glass pipette. The volume of water extracted from plexiglass corer ranged between 400 and $500 \mathrm{ml}$.

The abundance and biomass of the bacteria were determined with the use of DAPI-4'6-diamino-2phenylindole (Porter \& Feig, 1980). $10 \mathrm{ml}$ of water was preserved in formaldehyde up to the final concentration of $2 \%$ and kept in darkness at $4{ }^{\circ} \mathrm{C}$. Preparations were made within $24 \mathrm{~h}$ after sampling. Sub-samples of $2 \mathrm{ml}$ were condensed on polycarbon filters coloured with Irgalan black (pore diameter of $0.2 \mu \mathrm{m})$. The contribution of active bacteria with intact membrane (MEM+) was analysed using LIVE/ DEAD BacLight Bacterial Viability Kits with two dyes: SYTO 9 and propidium iodide (PI), according to Schumann et al. (2003). SYTO 9 labels all bacteria with intact and damaged membranes, and PI penetrates bacteria with damaged membranes. A mixture of two stains was added (1:1, both dyes final concentration $0.15 \%$ ) for a $1 \mathrm{ml}$ subsample, incubated for $15 \mathrm{~min}$ at room temperature in the dark, filtered through a $0.2-\mu \mathrm{m}$-pore-size black polycarbonate membrane filter, and enumerated by epifluorescence microscope. 
The abundance and biomass of the heterotrophic flagellates (HF) were determined with primulin solution (Caron, 1983). $10 \mathrm{ml}$ of water was collected into dark-sterilized bottles. The samples were preserved in formalin up to the final concentration of $2 \%$ and they were kept in darkness at temperature of $4^{\circ} \mathrm{C}$. Four preparations were made from each sample. Subsamples of $10 \mathrm{ml}$ were condensed on $0.8 \mu \mathrm{m}$-poresize black nucleopore filters.

The abundance of testate amoebae and ciliates community composition were determined using Utermöhls method (Utermöhl, 1958). Testate amoebae and ciliates samples (three samples; whole sample $=500 \mathrm{ml}$ ) were sedimented for $24 \mathrm{~h}$ in cylinder, stopped with parafilm, then the upper volume of $400 \mathrm{ml}$ was gently removed. In order to determine the density and biomass, three samples were preserved with Lugol's solution. Additionally, observation of live samples was used for the taxonomic and trophic identification. Morphological identifications of the testate amoebae and ciliates were mainly based on works by Foissner \& Berger (1996), Foissner et al. (1999), Charman et al. (2000) and Clarke (2003). Bacterial biomass and size were determined by automated image analysis as described in Felip et al. (1995). Biovolumes of each microbial community were estimated by assuming geometric shapes and converting to carbon using the following conversion factor: heterotrophic bacteria: $1 \mu \mathrm{m}^{3}=5.6 \times$ $10^{-7} \mu \mathrm{gC}$; flagellates: $1 \mu^{3}=2.2 \times 10^{-7} \mu \mathrm{gC}$; ciliates and testate amoebae: $1 \mu^{3}=1.1 \times 10^{-7} \mu \mathrm{gC}$ (Gilbert et al., 1998a).

\section{Data analyses}

The significance of differences between mean density and biomass values of bacteria, flagellates, testate amoebae and ciliates was verified by means of ANOVA. Ordination methods were used to examine the general structure of the microbial loop data and test the link between the protozoa and environmental data. Because the length of the gradient was $>2$ standard deviations, canonical correspondence analysis (CCA), a method assuming unimodal species-environment relationships (Ter Braak, 1988-1992; MVSP, 2002). Correlation coefficients were calculated between pairs of variables in order to determine the relationships between particular components of the microbial loop.

\section{Results}

Abiotic variables

The water table depth was highly variable among sites and samples, ranging from 20 to $55 \mathrm{~cm}$. Statistically significant differences among the studied peatlands were found in their $\mathrm{pH}$, conductivity, chlorophyll $a$, $\mathrm{P}_{\text {tot }}, \mathrm{N}_{\mathrm{tot}}$, DOC and TOC (ANOVA, $F_{1.33}=62.11-$ 66.21, $P<0.001$ ). Among the studied peatlands, the highest average $\mathrm{pH}$ values were noted in a rich fen $(\mathrm{pH}=7.1-8.2)$ and the lowest in a raised bog $(\mathrm{pH}$ from 3.1 to 3.3). The concentrations of TOC and DOC reached their highest values in a raised bog; however, the remaining factors (conductivity, chlorophyll $a, \mathrm{P}_{\text {tot }}$, $\mathrm{N}_{\text {tot }}$ ) were at their maximum in a carbonate-rich fen (Table 1). A significantly higher Chl- $a$ content occurred before noon, compared to the night and morning $\left(F_{1.33}=72.71, P<0.001\right)$. The dynamics of diurnal concentrations of DOC was similar on the analysed peatlands. The maximum concentration was recorded before noon $\left(24 \mathrm{mg} \mathrm{l}^{-1}\right.$ in a raised bog and $13 \mathrm{mg}^{-1}$ in a carbonate fen), with another insignificant increase by night, and relatively clear increase early in the morning on the carbonate peat bog$6 \mathrm{mg} \mathrm{l}^{-1}\left(F_{1.23}=70.67, P<0.001\right)$ (Fig. 1a, b). The maximum concentration of $\mathrm{P}_{\text {tot }}$ and TOC was recorded in the morning $\left(0.256 \mathrm{mg} \mathrm{l}^{-1}\right.$ in a raised bog, $0.394 \mathrm{mg}^{-1}$ in a carbonate fen and $61 \mathrm{mg} \mathrm{l}^{-1}$ in a raised bog, $26 \mathrm{mg}^{-1}$ in a carbonate fen, respectively). WTD, pH, DO, conductivity and $\mathrm{N}_{\text {tot }}$ did not show significant differences in diurnal dynamics.

Microbial communities

An insignificantly higher average annual number and biomass of bacteria for the period April-November 2009 were recorded in the raised bog $(7.5 \pm 2.2 \times$ $10^{6}$ cell ml $^{-1}$ and $0.93 \pm 0.36 \mu \mathrm{gC} \mathrm{ml}^{-1}$, respectively). Much lower values occurred in the carbonate fen $\left(5.5 \pm 2.1 \times 10^{6}\right.$ cell ml $^{-1}$ and $0.53 \pm 0.20$ $\left.\mu \mathrm{gC} \mathrm{ml}{ }^{-1}\right)\left(F_{1.34}=36.59, P \leq 0.001\right)$. In the raised $\mathrm{bog}$, the number of bacteria was very low in autumn and reached its maximum in summer, while in the carbonate fen, the highest number of bacteria occurred in autumn and the lowest in spring (Fig. 2a). A comparison of the abundance and biomass of microbial loop components between Sphagnum mosses in the raised bog did not show significant differences 

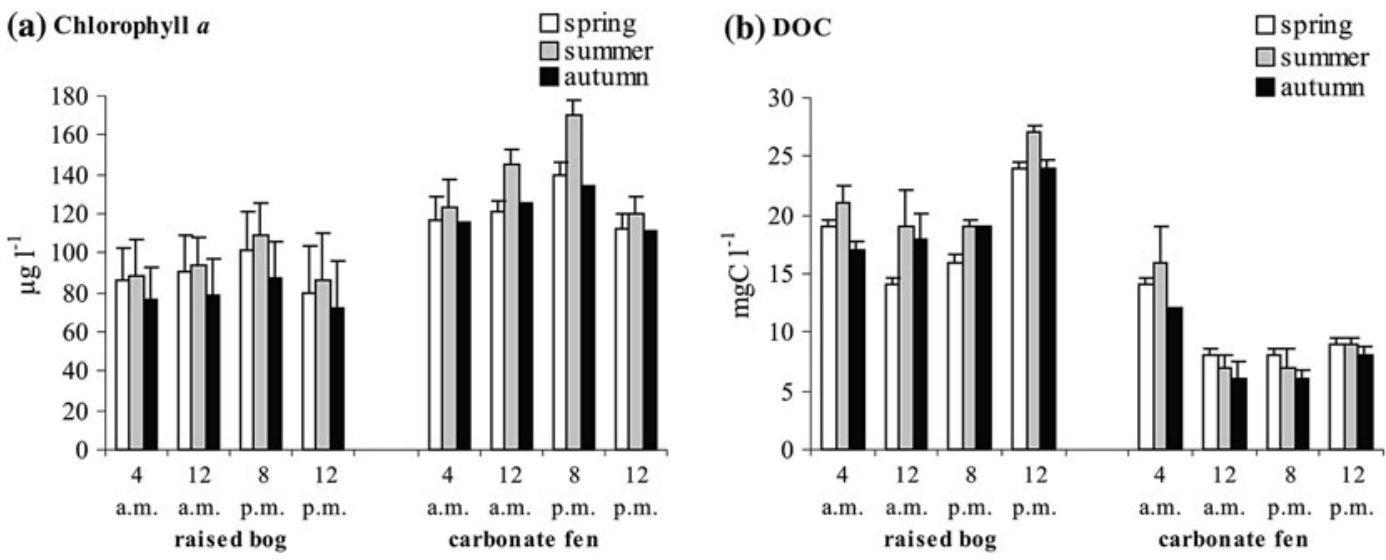

Fig. 1 a, b Diurnal dynamics of the concentrations of chlorophyll $a$ and DOC in investigated peatlands ( $T S D$ standard deviation)

(ANOVA, $F_{3.11}=0.679, P=0.570$ ). These differences were significant for patches of plants in carbonate peat bogs (ANOVA, $F_{2.9}=8.668, P=$ 0.0013). The highest abundance and biomass of bacteria and heterotrophic protists was found in Utricularia and Calliergonella $\left(>6 \times 10^{6}\right.$ cell ml $^{-1}$ and $0.83 \mu \mathrm{gC} \mathrm{ml} l^{-1}$ and $>2 \times 10^{3}$ cell ml $\mathrm{md}^{-1}$ and $0.04 \mu \mathrm{gC} \mathrm{ml}^{-1}$, respectively), and the lowest was observed in the Typha, Phragmites and Carex belts. Irrespective of the type of peatland, metabolically active bacteria (MEM+) reached from $12 \%$ to $24 \%$. The number of bacteria in the diurnal cycle was subject to quite significant changes in the analysed peatlands $\left(F_{1.34}=37.56, P \leq 0.001\right)$. In the raised bog, the lowest number was recorded in the evening and night $\left(6.0-6.5 \pm 1.2-1.0 \times 10^{6}\right.$ cell ml $\left.^{-1}\right)$, and the highest number occurred before noon and in the afternoon $\quad\left(7.0-8.5 \pm 1.0-1.1 \times 10^{6} \quad\right.$ cell ml $\left.{ }^{-1}\right)$ (Fig. 2a). Analogical changes concerned the biomass and metabolic activity of bacteria (Figs. 3, 4a). In the carbonate fen, the maximum bacterial number and biomass were recorded in the morning $(6.1 \pm 2.2 \times$ $10^{6}$ cell $\mathrm{ml}^{-1}$ and $0.59 \pm 0.19 \mu \mathrm{gC} \mathrm{ml}^{-1}$ ). Another, insignificant increase occurred at night. A substantial increase in the participation of metabolically active bacteria was determined before noon (from 12 to 23\%) (Figs. 3, 4a).

The highest average annual number and biomass of $\mathrm{HF}$ were determined in the raised bog $(2.8 \pm 1.1 \times$ $10^{3}$ cell $\mathrm{ml}^{-1}$ and $0.03 \pm 0.01 \mu \mathrm{gC} \mathrm{ml}^{-1}$ ). Lower mean values were recorded in the carbonate fen $(1.8 \pm$ $0.8 \times 10^{3}$ cell ml${ }^{-1}$ and $0.02 \pm 0.01 \mu \mathrm{gC} \mathrm{ml}^{-1}$ ) $\left(F_{1.21}=26.32, P \leq 0.001\right)$. In all studied peat bogs, the maximum abundance of HF was noted in spring, and the lowest in autumn. In the diurnal cycle, the largest changes in both the number and the biomass of HF occurred in the raised bog, where the highest number was observed in the morning $(3.1 \pm 0.8 \times$ $10^{3}$ cell ml${ }^{-1}$ and $\left.0.05 \pm 0.02 \mu \mathrm{gC} \mathrm{ml}^{-1}\right)\left(F_{1.31}=\right.$ $36.66, P \leq 0.001)$. In the carbonate fen, an approximately twofold increase in the number was observed at 12 p.m. $\left(2 \pm 0.3 \times 10^{3}\right.$ cell ml $\left.^{-1}\right)$. In the afternoon and at night, a gradual decrease was determined $\left(F_{1.30}=31.64, \quad P \leq 0.001\right) \quad$ (Fig. $\left.2 b\right)$. Biomass was subject to analogical changes $\left(F_{1.14}=13.04\right.$, $P \leq 0.005$ ) (Fig. 4b).

A lower diurnal cycle of changes in the abundance and biomass of testate amoebae was also observed; however, the differences were not significant. Irrespective of the type of peatland and season, a higher abundance and biomass of those organisms were recorded in the afternoon (4.1-4.2 $\pm 1.1-1.2 \times$ $10^{2}$ cells ml ${ }^{-1}$ and $0.91-1.1 \pm 0.1-0.2 \mu \mathrm{gC} \mathrm{ml}^{-1}$ ) $\left(F_{1.41}=17.12, P>0.05\right)$. In the raised bog, the maximum value was noted in summer. In the carbonate fen, the highest number of testate amoebae was noted in spring. In the raised bog, Assulina reached the highest participation at the time, and in the carbonate fen-Arcella. The lowest number and biomass were recorded at night $\left(1.8-2.0 \times 10^{2}\right.$ cells ml ${ }^{-1}$ and $0.5-0.7 \mu \mathrm{gC} \mathrm{ml}{ }^{-1}$ ) (Figs. 2c, 4c).

The peatlands also differed in terms of the average number and biomass of ciliates. A higher number was recorded in the raised bog $\left(55 \pm 11\right.$ cells $\left.\mathrm{ml}^{-1}\right)$, while the average number in the carbonate fen was almost

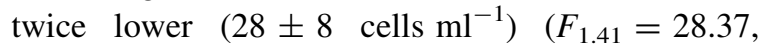
$P \leq 0.001)$. Higher individual weight of ciliates in the carbonate-rich fen resulted in their higher biomass 

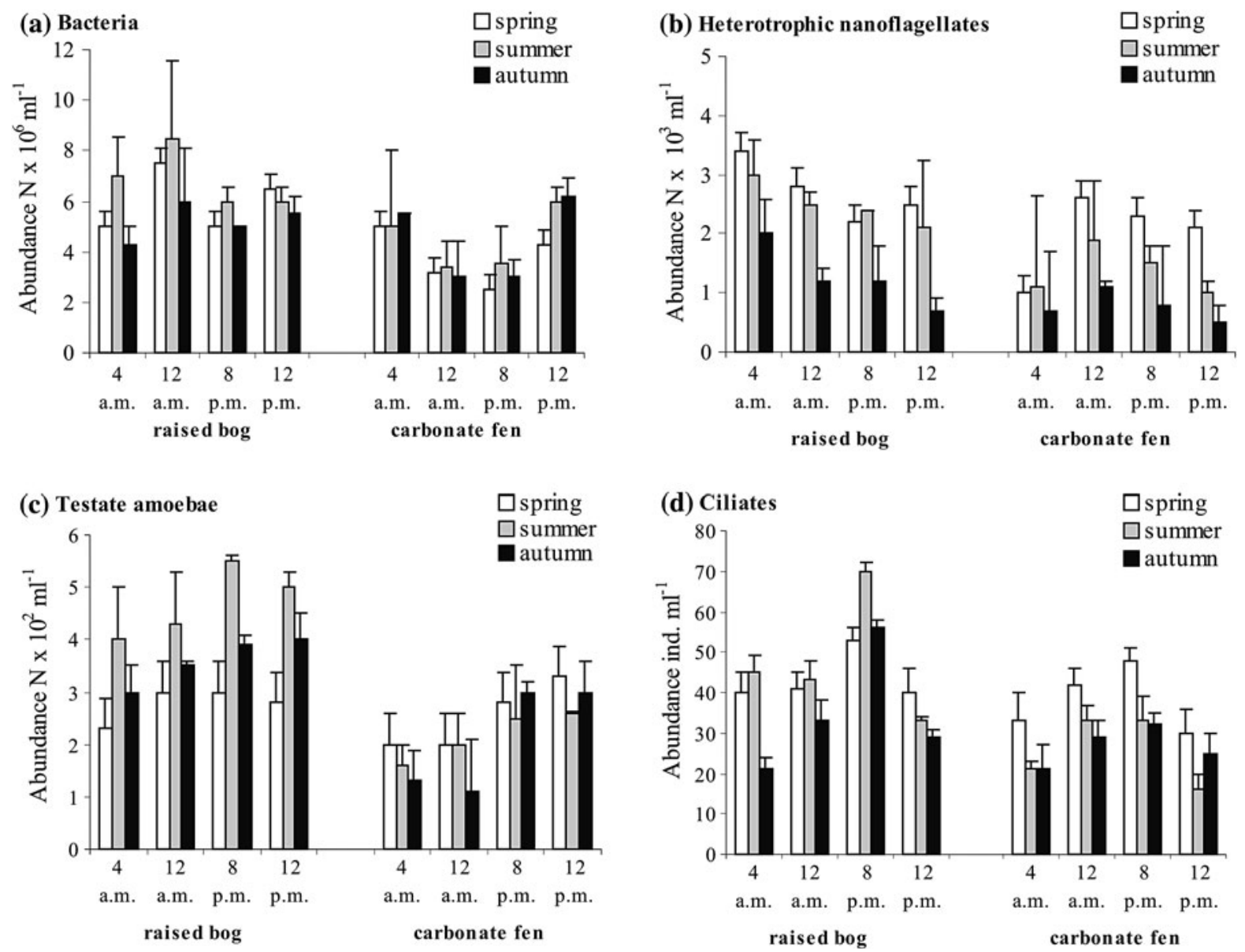

Fig. 2 a, d Diurnal dynamics of the density of bacteria, HF, testate amoebae and ciliates in investigated peatlands ( $\top S D$ standard deviation)

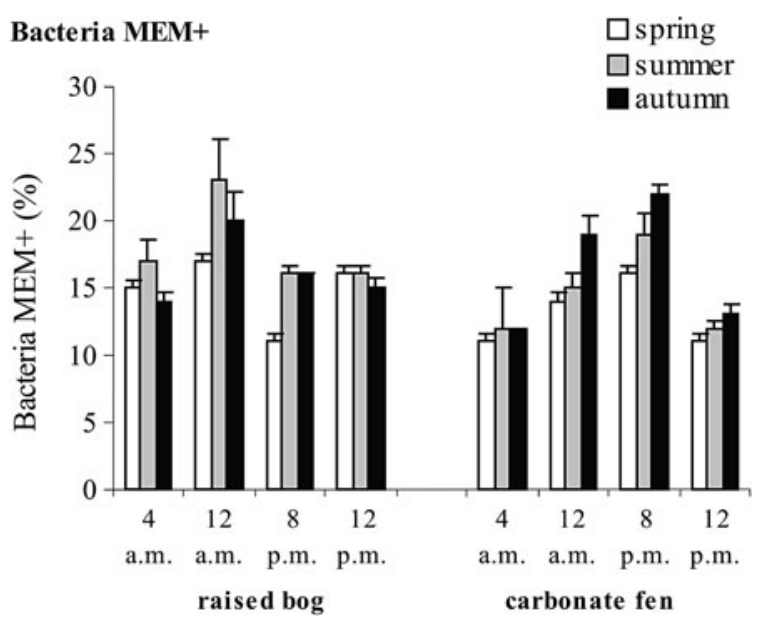

Fig. 3 Diurnal dynamics of the percentage contribution of active cells $(\mathrm{MEM}+)$ to the total numbers of bacteria in investigated peatlands ( $T S D$ standard deviation) $\left(>0.6 \pm 0.2 \mu \mathrm{gC} \mathrm{ml}^{-1}\right)$. In the raised bog, the number of ciliates was very low in spring and reached its maximum in summer. In the carbonate fen, the lowest number of ciliates occurred in summer, and reached its peak values in spring (Fig. 4d). Irrespective of the type of peatland, a significantly higher abundance of ciliates was recorded in the afternoon (from 56 to $75 \pm 12$ cells ml${ }^{-1}$ ), and biomass early in the morning (from 0.6 to $\left.0.7 \pm 0.1 \mu \mathrm{gC} \mathrm{ml}^{-1}\right)\left(F_{1.15}=12.07\right.$, $P \leq 0.005)$. In the first case, small bacteriovorous Cinetochilum sp. was predominant, and in the second case, large mixotrophic Coleps hirtus. The lowest number and biomass were observed at night (Figs. 2d, $4 d)$. The results showed high variability regarding the number and biomass of bacterial and heterotrophic protists between replicated samples. The highest variability was observed in the raised bog, in which $\mathrm{HF}$ abundance was more variable (coefficient of 

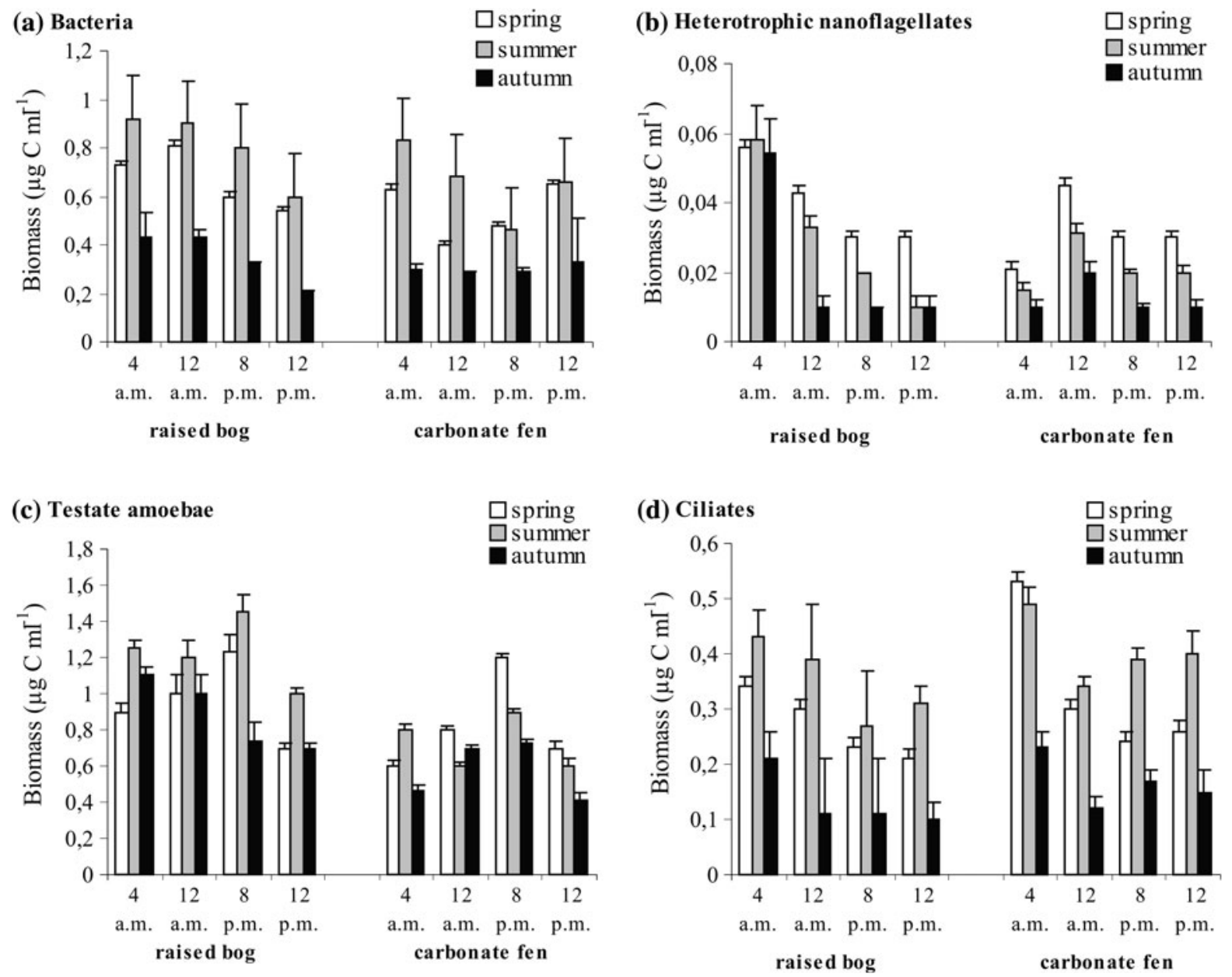

Fig. 4 a, d Diurnal dynamics of the biomass of bacteria, HF, testate amoebae and ciliates in investigated peatlands ( $T S D$ standard deviation)

variation: $\mathrm{CV}=60 \%)$ than the bacteria $(\mathrm{CV}=43 \%)$, ciliates $(\mathrm{CV}=11 \%)$ and testate amoebae $(\mathrm{CV}=$ $3 \%)$. In the carbonate fen, the variability was lower and ranged between $\mathrm{CV}=17$ and $21 \%$ for bacteria and $\mathrm{HF}$ to $\mathrm{CV}=5$ and $8 \%$ for testate amoebae and ciliates.

Relations among various components of the microbial loop and environmental factors

In the CCA of the microbial loop data, forward selection applied to the full set of environmental variables differentiated four variables with significant conditional effects: chlorophyll $a$, DOC, abundance of bacteria and nanoflagellates, which together accounted for $20 \%$ of the variability (Fig. 5A, B). $\mathrm{DOC}$ and heterotrophic bacteria were the strongest contribution to the model, accounting for $16 \%$ of the variability in the structure of the protists community. Chlorophyll $a$ and flagellates accounted for only $4 \%$ of the variability of the protozoa community structure $(P<0.001)$ (Fig. 5A, B). Generally, the abundance of testate amoebae and ciliates were correlated with DOC, abundance of bacteria MEM+ and HF (from $r=0.37, P \leq 0.05$ to $r=0.59, P \leq 0.01, n=56$ ) (Table 2). However, the number of significant correlations between the main groups of microorganisms forming the microbial loop varied among the sites. In the raised bog, the relations between microbial loop components were stronger. Bacterial density correlated positively with the density of testate amoebae $(r=0.51, P \leq 0.01)$ and bacterivorous Colpodea ( $r=0.51, P \leq 0.01$ ). The density of HF correlated positively with the abundance of testate amoebae 
( $r=0.47, P \leq 0.01$ ). In the carbonate fen the total number of active bacteria correlated positively with the density of Cyrtophorida feeding on bacteria, flagellates and algae $(r=0.33, P \leq 0.05)$. The most significant relationship in the carbonate peat bog was found between the density of testate amoebae and density of bacteria $(r=0.50, P \leq 0.01)$ and flagellates $(r=0.52, P \leq 0.01)$ (Table 2$)$. The number of correlations and the degree of component correlation of the microbial loop in the diurnal cycle presented itself differently. In the raised bog, a substantially higher number of more statistically significant correlations between all components of the loop were determined. The most significant correlations occurred in the afternoon. At that time, the number and biomass of metabolically active bacteria were most strongly correlated with DOC $(r=0.51, r=0.61$, $P \leq 0.01$ ), and in the evening, a clearly positive correlation between the abundance of bacteria and protists was observed (from $r=0.58$ to $r=0.67$, $P \leq 0.01)$. In raised bog, in the diurnal cycle, the components of the microbial loop correlated with DOC. In the carbonate fen, the correlations were significantly weaker (from $r=0.38, P \leq 0.05$ to $r=0.47, P \leq 0.01)$. In the diurnal dynamics, only some microbial loop components and environmental variables are strongly and significantly correlated. The majority of significant correlations were negative. In both types of peatland, the highest significant negative values of correlation coefficient were calculated for $\mathrm{pH}, \mathrm{DO}$ and abundance of bacteria and heterotrophic protists in the evening $(r=-0.78, P \leq 0.01$ and $r=-0.69, P \leq 0.01$, respectively). In the morning, all components of microbial loop correlated positively with $\mathrm{P}_{\text {tot }}$ and TOC ( $\left.r=0.75-0.77, P \leq 0.01\right)$.

\section{Discussion}

Testate amoebae were the dominant microbial group in the total biomass of heterotrophic microorganisms in all of the studied peatlands. Bacteria were the second dominant group. HF and ciliates comprised only a small proportion of the total microbial biomass. Similar relations were observed in the peatlands of the French Massif Central (Gilbert et al., 1998b). According to Gilbert et al. (1998b), testate amoebae accounted for $48 \%$ of the total biomass, heterotrophic bacteria $15 \%$, while $\mathrm{HF}$ and ciliates $1-2 \%$ only accounted for a low proportion of total microbial biomass. Both the biomass and the abundance of the microbial loop components were merely similar for different species of mosses. Similar regularities were observed in protozoan communities inhabiting the raised peat bogs of the lake-wetland region of 'Polesie Lubelskie' in Eastern Poland (Mieczan, 2007). The lack of any statistically significant differences in the abundance of bacteria and heterotrophic protists may be related to the fact that all moss species were situated in sphagnum hollows with waters of similar physical and chemical properties. On the other hand, in a carbonate peat bog, both the abundance and the biomass of bacteria and heterotrophic protists were clearly varied among the individual plant species. It was observed in this study that the abundance and biomass of bacteria and heterotrophic protists increased with the abundance and level of the complicated structure of peat bog plants. The most structurally complex plants with a 'dense' shoot structure may prove more environmentally attractive for microbial loop components-with better food provision and refuge. It was observed in this study that among Utricularia and Calliergonella the concentrations of TOC and total phosphorus were several times higher, which could influence the abundance of food. The species communities for the peat bogs of Eastern Poland show a reasonable similarity with the results of other quantitative and qualitative studies of protists' ecology, in the peat bogs of other regions (Jassey et al., 2010, Lamentowicz et al., 2010). Protist communities demonstrated an evident correlation with the concentration of TOC and total phosphorus. Also, in the raised peat bogs of Western Europe, it was observed that the moisture of the habitat, $\mathrm{pH}$ and the content of nutrients in the water had a significant effect on the occurrence of these microorganisms (Mitchell et al., 2000). In the investigated peatlands, metabolically active bacteria reached from 12 to $24 \%$. The results of studies conducted by Jugnia Louris et al. (2006) in peatlands suggested that the mean contribution of MEM+ ranged from 15 to $30 \%$ in the total bacterial number. Mitchell et al. (2003) demonstrated that heterotrophic bacteria were the dominant microbial group and testate amoebae dominated only in the protozoan biomass in five Sphagnum-dominated peatlands across Europe. These differences can be explained by the fact that the study was conducted on a habitat with a higher water content. The relatively 


\section{(A) Testate amoebae}

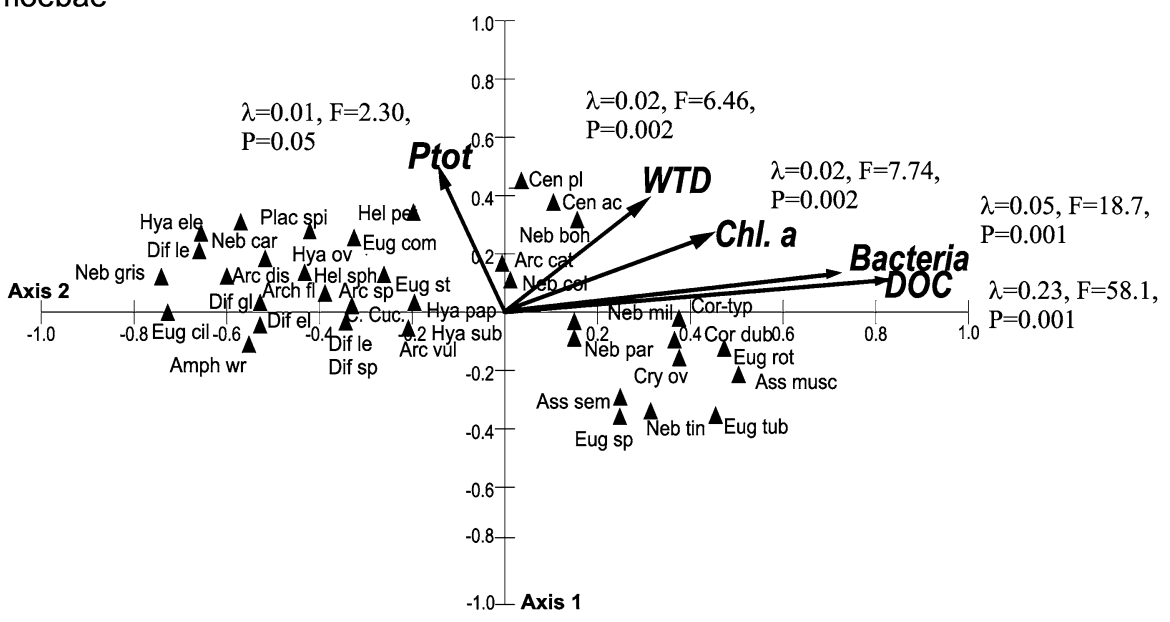

Vector scaling: 0,80

(B) Ciliates

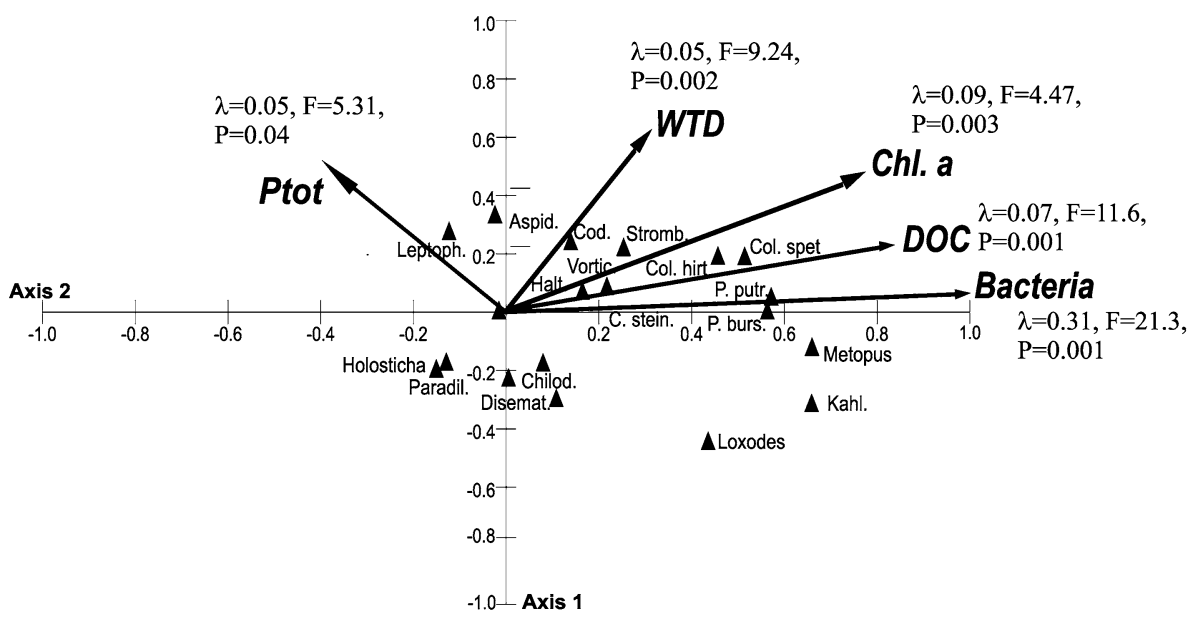

Vector scaling: 0,80

Fig. 5 A, B Biplots of the CCA analysis of testate amoebae and ciliates data from investigated peatlands with representation of species and environmental variables. Species data were logtransformed, and rare species were down-weighted. A Testate amoebae: (Amph wr.-Amphitrema wrightianum, Arc cat.Arcella catinus type, Arc dis.-Arcella disoides type, Arc sp.Arcella sp., Arc vul.-Arcella vulgaris, Arch fl.-Archerella flavum, Ass musc.-Assulina muscorum, Ass sem.-Assulina seminulum, Cen ac.-Centropyxis aculeata type, Cen pl.Centropyxis platystoma type, Cor dub.-Corythion dubium, Cor typ-Corythion-Trinema type, Cry ov.-Cryptodifflugia oviformis, Dif gl._Difflugia globulosa, Dif el._Difflugia elegans, Dif le.-Difflugia leidyi, Dif sp.-Difflugia sp., Eug cil.Euglypha ciliata, Eug com.-Euglypha compressa, Eug rot.Euglypha rotunda type, Eug sp.-Euglypha sp., Eug st.Euglypha strigosa, Eug tub.-Euglypha tuberculata type, Hel pet.-Heleoptera petricola, Hel sph.-Heleoptera sphagnii, Hya ele.-Hyalosphenia elegans, Hya ov.-Hyalosphenia ovalis, Hya pap.-Hyalosphenia papilio, Hya sub.-
Hyalosphenia subflava, Neb boh.-Nebela bohemica, Neb car.-Nebela carinata, Neb col.- Nebela collaris, Neb gris.Nebela griseola type, Neb mil.-Nebela militaris, Neb par.Nebela parvula, Neb sp.-Nebela sp., Neb tin.-Nebela tincta, Plac spin._Placocista spinosa type, Trig arc.-Trigonopyxis arcula). B Ciliates: (Aspid.-Aspidisca sp., Caenomprph.Caenomorpha spp., Chilod.-Chilodonella uncinata, Cinet.Cinetochilum margaritaceum, Cod.-Codonella cratera, Col. hirt.-Coleps hirtus, Col. spet.-Coleps spetai, C. stein.Colpoda steinii, C. cuc._Colpoda cucullus, C. stein._Colpoda steinii, Disemat.—Disematostoma tetraedricum, Euplot.-Euplotes sp., Kahl.-Kahlilembus attenuotus, Halt.-Halteria grandinella, Holosticha-Holosticha pullaster, Leptoph.-Leptopharynx costatus, Loxodes-Loxodes striatus, MetopusMetopus es, Paradil.-Paradileptus elephantinus, P. burs.Paramecium bursaria, P. putr.-Paramecium putrinum, Stromb.—Strombidium viride, Styl.—Stylonychia mytilusKomplex, Vortic._Vorticella companula) 
Table 2 Linear correlation coefficients between microbial loop components in the investigated peatlands

\begin{tabular}{|c|c|c|c|c|c|c|c|c|c|c|c|c|}
\hline & \multirow[t]{2}{*}{ DOC } & \multicolumn{5}{|l|}{ Raised bog } & \multirow[t]{2}{*}{ DOC } & \multicolumn{5}{|c|}{ Carbonate fen } \\
\hline & & $\begin{array}{l}\text { Bacteria- } \\
\text { total no. }\end{array}$ & $\begin{array}{l}\text { Bacteria } \\
\text { MEM+ }\end{array}$ & HNF & $\begin{array}{l}\text { Testate } \\
\text { amoebae }\end{array}$ & Ciliata & & $\begin{array}{l}\text { Bacteria- } \\
\text { total no. }\end{array}$ & $\begin{array}{l}\text { Bacteria } \\
\text { MEM+ }\end{array}$ & $\mathrm{HNF}$ & $\begin{array}{l}\text { Testate } \\
\text { amoebae }\end{array}$ & Ciliata \\
\hline DOC & - & & & & & & - & & & & & \\
\hline $\begin{array}{c}\text { Bacteria- } \\
\text { total no. }\end{array}$ & $0.25^{*}$ & - & & & & & $0.35^{*}$ & - & & & & \\
\hline $\begin{array}{c}\text { Bacteria } \\
\text { MEM+ }\end{array}$ & $0.27 *$ & & - & & & & $0.54 * *$ & & - & & & \\
\hline $\mathrm{HNF}$ & & $0.23 *$ & & - & & & & & & - & & \\
\hline Testate amoebae & $0.39 *$ & $0.51 * *$ & $0.59 * *$ & $0.47 * *$ & - & & $0.37 *$ & $0.50 *$ & $0.49 * *$ & $0.52 * *$ & - & \\
\hline Ciliata & $0.33 *$ & $0.51 * *$ & $0.55 * *$ & & & - & $0.31 *$ & $0.34 *$ & $0.44^{*}$ & & & - \\
\hline Colpodea & & $0.51 * *$ & $0.36^{*}$ & $0.34 *$ & & & & & & & & \\
\hline Cyrtophorida & & $0.23 *$ & & & & & & & $0.33^{*}$ & & & \\
\hline \multicolumn{13}{|l|}{ Haptorida } \\
\hline \multicolumn{13}{|l|}{ Hypotrichida } \\
\hline \multicolumn{13}{|l|}{ Heterotrichida } \\
\hline Nassulida & & $0.33^{*}$ & & & & & & & & & & \\
\hline Oligotrichida & & $0.27 *$ & $0.29 *$ & $0.33^{*}$ & & & & $0.25^{*}$ & & & & \\
\hline \multicolumn{13}{|l|}{ Pleurostomatida } \\
\hline \multicolumn{13}{|l|}{ Prostomatida } \\
\hline \multicolumn{13}{|l|}{ Peritrichida } \\
\hline Scuticociliatida & & $0.33 *$ & $0.37 *$ & & & & & & & & & \\
\hline Suctorida & & & & & & & & & & & & \\
\hline
\end{tabular}

** $P \leq 0.01, * P \leq 0.05$

high abundance of ciliates in this study is probably due to a high competitive capacity of bacteria developing in higher numbers. The abundance and biomass of testate amoebae and ciliates were significantly higher in the raised bog. Generally, in this study, the abundance of testate amoebae and ciliates were correlated with the total abundance of bacteria, bacteria MEM+ and HF. In the seasonal cycle, testate amoebae probably played an important role in reducing bacteria and HF abundances. This knowledge is based on 2 basic factors: testate amoebae abundance is 1-2 orders higher than that of ciliates, and testate amoebae are considered to graze on the most common co-occurring microorganisms, as well as on other protists (Jassey et al., 2012). Gilbert et al. (1998a, b) documented that the abundance of testate amoebae is significantly related to the abundance of $\mathrm{HF}$ and ciliates. In the studied peatlands, the density of bacterivorous taxa (Colpodea and Scuticociliatida) and omnivorous taxa (Cyrtophorida) correlated positively with the density of bacteria (MEM+). These studies suggest that protists were the main consumer of bacteria in peatlands with different $\mathrm{pH}$ values. In this study, changes in the number of bacteria were not strongly related to DOC concentrations. This suggested that grazing might be a crucial factor in controlling bacterial density. It was found, however, that various taxonomic and trophic groups of ciliates showed different correlations with bacterial abundance in particular peat bogs. Kankaala et al. (1996) noted close correlations between the biomass of HF and the biomass of ciliates in humic lakes. Amblard et al. (1995) demonstrated that ciliates were an important consumer of bacteria. The highest variability of microbial loop components in the raised bog suggested that microbial loop communities were strongly regulated by bottom-up and top-down controls. In world ecological studies, only one publication regarding abundance of $\mathrm{HF}$ and their ecological role in peatlands was noted (Gilbert et al., 1998a).

The studies conducted by Gilbert et al. (1998b) indicate that abundance and biomass of HF are weakly correlated with bacteria. In this study, the correlation between bacterial abundance and HF was not found. 
Hansen \& Christoffersen (1995) suggested that HF grazed preferentially on bigger bacterial cells, while in the investigated peatlands, bacterial size distribution was dominated by small cells. However, in the rich fen an increase in flagellates higher than $10 \mu \mathrm{m}$ was observed. Many of these larger forms not only feed on bacteria but also ingest algae and other flagellates; therefore, they seem to depend on higher algae concentrations. Similar results were observed in lakes in Germany (Auer \& Arndt, 2001). In the diurnal cycle, the highest abundance of testate amoebae and ciliates occurred in the afternoon. Another increase was observed in the morning. At this time, also the lowest chlorophyll $a$ concentration was recorded, along with relatively high abundance of bacteria. In the raised bog, the maximum number of ciliates was correlated with an increase in the number of flagellates. Comparable data on the dynamics of diurnal changes in individual components of the microbial loop in peatland ecosystems are still scarce. As evidenced by the studies carried out by Šimek \& Straskrabova (1992) in environments with low fertility, the rate of bacteria consumption by heterotrophic protists in the afternoon is almost two times higher than at night and early in the morning. In this study, an increase in the abundance of ciliates in the afternoon could be related to the highest concentrations of chlorophyll $a$. Additionally, DOC probably indirectly influenced an increase in the number and biomass of heterotrophic protists. As numerous studies have revealed, the number of bacteria positively correlates with DOC concentrations in water, which also affects the number of heterotrophic protists (Mieczan, 2007). Correlations between DOC and abundance of bacteria were particularly visible in the carbonate fen. Such correlations did not occur, or were insignificant in the raised bog. This probably results from the fact that the chemical composition and availability of DOC are more significant in the development of heterotrophic bacteria than their amount. According to the studies carried out by Chróst \& Siuda (2006), particles included in the composition of DOC, so-called refractors, are available only after enzymatic decomposition. Moreover, significant correlations occur between concentrations of DOC produced by algae, whereas such correlations often do not occur with total DOC (Chróst \& Siuda, 2006). An increase in the abundance of nanoflagellates in the morning probably resulted from low pressure of ciliates. At the time, a significant decrease in the abundance and biomass of mixotrophic ciliates was observed. Due to low light penetration caused by humic substances, the ciliates could turn to a more heterotrophic manner of feeding. In the carbonate peat bog, the maximum number and biomasses of flagellates were observed during the day, which may be also related to a lower abundance of other protists. Their low number in the evening and at night may result from the consumption of those organisms by amoebae and ciliates, or larger Metazoa (mainly Rotatoria and Calanoida, predominating on those peatlands). According to Mieczan (2010), Metazoa are known to prey intensively on flagellates and can easily affect their number. It seems that in the peatlands studied, a very specific microbial loop occurs, in which the bacteria-testate amoebae/ciliates system is predominant, and the participation of flagellates in bacteria consumption is marginalized. The fact seems to be also confirmed by a change in bacterial metabolic activity along with an increase in abundance of amoebae and ciliates. Irrespective of the type of peatland, the participation of cells of metabolically active bacteria decreased, particularly in the morning, along with an increase in the numbers of those protozoa. According to the studies carried out by del Giorgio et al. (1996), the rate of consumption of metabolically active bacteria increases fourfold in relation to the consumption of inactive or dead bacteria. On the other hand, an increase in the participation of inactive or 'dormant' bacteria may also constitute one of the protection mechanisms against the pressure of protozoa.

Our study suggests that the abundance and biomasses of particular components of the microbial loop markedly differed between the peatlands. The raised bog was characterised by the highest abundance and biomass of all biotic components of the microbial loop compared with the carbonate fen. The relationship between bacteria and protists suggests a significant process of transferring carbon to higher trophic levels, whereas significant diurnal correlations between individual components of the loop in peatlands with low $\mathrm{pH}$ and low fertility (raised bog) are more numerous and statistically more significant. In the raised bog, the role of HF in grazing on bacteria decreases and that of testate amoebae increases. The most significant correlations occurred in the afternoon. At that time, the number and biomass of bacteria were most closely correlated with concentrations of DOC, and in the 
evening, a clearly positive correlation between the abundance of bacteria and heterotrophic protists was observed. In the carbonate fen, the correlations were significantly weaker. In the dial cycle, all components of the microbial loop were strongly correlated with the concentrations of total phosphorus and TOC. In general terms, these results seem to confirm the hypothesis that fertility of a habitat may significantly influence the diurnal dynamics of the abundance of individual components of the microbial loop, as well as the number and intensity of correlations between bacteria and protists.

Acknowledgments This work was financially partly by the project No. N304 209837 from the Ministry of Science and Higher Education and by the project 2012/05/B/NZ8/01263 from National Science Centre, Poland.

Open Access This article is distributed under the terms of the Creative Commons Attribution License which permits any use, distribution, and reproduction in any medium, provided the original author(s) and the source are credited.

\section{References}

Amblard, C., J. Carrias, F. Bourdier \& N. Maurin, 1995. The microbial loop in a humic lake: seasonal and vertical variations in the structure of different communities. Hydrobiologia 300(301): 71-84.

Auer, B. \& H. Arndt, 2001. Taxonomic composition and biomass of heterotrophic flagellates in relation to lake trophy and season. Freshwater Biology 46: 959-972.

Azam, F., T. Fenchel, J. G. Field, J. S. Gray, L. A. Mayer-Reil \& F. Thindstad, 1983. The ecological role of water-column microbes in the sea. Marine Ecology 10: 257-263.

Caron, D. A., 1983. Technique for enumeration of heterotrophic and phototrophic nanoplankton, using epifluorescence microscopy and comparison with other procedures. Applied and Environment Microbiology 46: 491-498.

Charman, D. J., D. Hendon, \& W. Woodland, 2000. The identification of testate amoebae (Protozoa: Rhizopoda) in peats. Technical Guide 9. Quaternary Research, London: $1-147$.

Chróst, R. J. \& W. Siuda, 2006. Microbial production, utilization, and enzymatic degradation of organic matter in the upper trophogenic layer in the pelagial zone of lakes along a eutrophication gradient. Limnology \& Oceanography 5: 749-762.

Chróst, R. J., T. Adamczewski, K. Kalinowska \& A. Skowrońska, 2009. Abundance and structure of microbial loop components (bacteria and protists) in lakes of different trophic status. Journal of Microbiology and Biotechnology. doi:10.4014/jmb.0812.651.

Clarke, K. J., 2003. Guide to the Identification of Soil ProtozoaTeatate Amoebae. Freshwater Biological Association, UK
Del Giorgio, P. A., J. M. Gasol, D. Vaqu, P. Mura, S. Agusti \& C. M. Duarte, 1996. Bacterioplankton community structure: protists control net production and the proportion of active bacteria in a coastal marine community. Limnology \& Oceanography 41: 1169-1179.

Felip, M., B. Sattler, R. Psenner \& J. Catalan, 1995. Highly active microbial communities in the ice and snow cover of high mountain lakes. Applied Environmental Microbiology 61: 2394-2401.

Foissner, W. \& H. Berger, 1996. A user-friendly guide to the ciliates (Protozoa, Ciliophora) commonly used by hydrobiologists as bioindicators in rivers, lakes and waste waters, with notes on their ecology. Freshwater Biology 35: $375-470$.

Foissner, W., H. Berger \& J. Schaumburg, 1999. Identification and Ecology of Limnetic Plankton Ciliates. Informationsberichte des Bayer, Landesamtes für Wasserwirtschaft, München.

Gilbert, D., C. Amblard, G. Bourdier \& A. J. Francez, 1998a. The microbial loop at the surface of a peatland: structure, functioning and impact of nutrients inputs. Microbial Ecology 35: 89-93.

Gilbert, D., C. Amblard, G. Bourdier \& A. J. Francez, 1998b. Short-term effect of nitrogen enrichment on the microbial communities of a peatland. Hydrobiologia 373(374): 111-119.

Golterman, H. L., 1969. Methods for Chemical Analysis of Freshwaters. Blackwell Scientific Publications, Oxford.

Hansen, B. \& K. Christoffersen, 1995. Specific growth rates of heterotrophic plankton organisms in a eutrophic lake during a spring bloom. Journal of Plankton Research 17: 413-430.

Jassey, V. E. J., G Chiapusio, E. A. D. Mitchell, P. Binet, M. L. Toussaint \& D. Gilbert, 2010. Fine-scale horizontal and vertical micro-distribution patterns of testate amoebae along a narrow fen/bog gradient. Microbial Ecology. doi: 10.1007/S00248-010-9756-9.

Jassey, V. E. J., S. Shimano, C. Dupuy, M. Toussaint \& D. Gilbert, 2012. Characterizing the feeding habits on the testate amoebae Hyalosphenia papilio and Nebela tincta along narrow "fen-bog" gradient using digestive vacuole content and ${ }^{13} \mathrm{C}$ and ${ }^{15} \mathrm{~N}$ isotopic analyses. Protist 163 : $451-464$.

Jugnia Louris, B., R. Roy, M. Pacheco-Oliver, D. Planas, C. B. Miguez \& C. W. Greer, 2006. Potential activity and diversity of methanotrophic bacteria in forest soil, peat, and sediments from a hydroelectric reservoir (Robert-Bourassa) and lakes in the Canadian taiga. Soil Sciences 2: 127-137.

Kalinowska, K., 2004. Bacteria, nanoflagellates and ciliates as components of the microbial loop in three lakes of different status. Polish Journal of Ecology 54: 19-34.

Kankaala, P., L. Arvola, T. Tulonen \& A. Ojala, 1996. Carbon budget for the pelagic food web of the euphotic zone in a boreal lake (Lake Pääjärvi). Canadian Journal of Fishery and Aquatic Sciences 53: 1663-1674.

Lamentowicz, M., Ł. Lamentowicz, W. O. van der Knaap, M. Gąbka \& E. A. D. Mitchell, 2010. Contrasting speciesenvironment relationships in communities of testate amoebae, bryophytes and vascular plants along the fen-bog gradient. Microbial Ecology 59: 499-510. 
Macek, M., K. Simek \& T. Bittl, 2001. Conspicuous peak of oligotrichous ciliates following winter stratification in a bog lake. Journal of Plankton Research 23: 353-363.

Mieczan, T., 2007. Seasonal patterns of testate amoebae and ciliates in three peabogs: relationship to bacteria and flagellates (Poleski National Park, Eastern Poland). Ecohydrology \& Hydrobiology 1: 79-88.

Mieczan, T., 2010. Vertical micro-zonation of testate amoebae and ciliates in peatland waters in relation to potential food resources and grazing pressure. International Review of Hydrobiology 1: 86-102.

Mieczan, T., I. Bielańska-Grajner \& M. Tarkowska-Kukuryk, 2012. Hydrochemical and microbiological distinction and function of ombrotrophic peatland lagg as ecotone between Sphagnum peatland and forest catchment (Poleski National Park, eastern Poland). Annales de Limnologae - International Journal of Limnology 48: 323-336.

Mitchell, E. A. D., A. Buttler, Ph. Grosvernier, H. Hydin, C. Albinsson, A. L. Greenup, M. M. P. D. Heijmans, M. R. Hoosbeek \& T. Saarinen, 2000. Relationships among testate amoebae (Protozoa), vegetation and water chemistry in five Sphagnum-dominated peatlands in Europe. New Phytology 145: 95-106.

Mitchell, E. A. D., D. Gilbert, A. Buttler, C. Amblard, P. Grosverinier \& J. M. Gobat, 2003. Structure of microbial communities in Sphagnum peatlands and effect of atmospheric carbon dioxide enrichment. Microbial Ecology 46: 187-199.

MVSP, 2002. Multivariate Statistical Package. Kovach Computing Services, Anglesey.
Nguyen-Viet, H., D. Gilbert, E. A. D. Mitchell, P. M. Badot \& N. Bernard, 2007. Effects of experimental lead pollution on the microbial communities associated with Sphagnum fallax (Bryophyta). Microbial Ecology 54: 232-241.

Payne, R. J., 2011. Can testate amoeba-based paleohydrology be extended to fens? Journal of Quaternary Sciences 26: $15-27$.

Payne, R. J. \& E. A. D. Mitchell, 2007. Ecology of testate amoebae from mires in the central Rhodope Mountains, Greece and development of a transfer function for paleohydrological reconstruction. Protists 158: 159-171.

Porter, K. G. \& Y. S. Feig, 1980. The use of DAPI for identification and counting aquatic microflora. Limnology \& Oceanography 25: 943-984.

Schumann, R., U. Schiewer, U. Karoten \& T. Rieling, 2003. Viability of bacteria from different aquatic habitats. II. Cellular fluorescent markers from membrane integrity and metabolic activity. Aquatic Microbial Ecology 32: 137-150.

Šimek, K. \& V. Straskrabova, 1992. Bacterioplankton production and protozoan bacterivory in a mesotrophic reservoir. Journal of Plankton Research 14: 773-787.

Ter Braak, C. J. F., 1988-1992. CANOCO-FORTRAN program for Canonical Community Ordination (vers. 2.1). Microcomputer Power, Ithaca.

Utermöhl, H., 1958. Zur vervollkommung der quantative phytoplankton methodic. Mitt International Verein Limnology 9: 1-38.

Wilkinson, D. M. \& E. A. D. Mitchell, 2010. Testate amoebae and nutrient cycling with particular reference to soils. Geomicrobiology Journal 27: 520-533. 